\title{
PREDIKSI KEBERLANGSUNGAN PERUSAHAAN SUB SEKTOR HOTEL, RESTORAN DAN PARIWISATA DI ERA PANDEMI COVID-19
}

\author{
Ni Luh Putu Uttari Premananda ${ }^{1}$

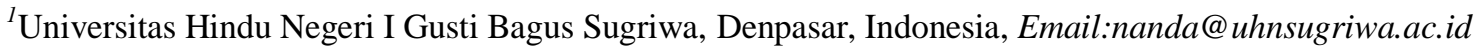

\begin{abstract}
ABSTRAK
Prediksi keberlangsungan usaha sangat penting dilakukan karena akan menggambarkan kondisi keuangan perusahaan sub sektor hotel, restoran dan pariwisata yang terdampak pandemi COVID-19. Sebanyak dua puluh sembilan (29) perusahaan sub sektor hotel, restoran dan pariwisata yang terdaftar di Bursa Efek Indoensia pada tahun 2020 menjadi objek penelitian. Dalam menilai keberlangsungan perusahaan, penelitian ini menggunakan model Altman Z-Score yang dimodifikasi, yang terdiri dari empat (4) rasio. Rasio-rasio tersebut antara lain: modal kerja dibagi total aset, laba ditahan dibagi total aset, EBIT dibagi total aset, dan book value of equity dibagi book value of liability. Dari model ini akan didapatkan nilai Z-Score masing-masing perusahaan, yang kemudian dikategorikan menjadi kategori Sehat, Rawan, dan Potensi Bangkrut. Penelitian ini menunjukkan bahwa, dari 29 perusahaan yang diuji, 12 di antaranya termasuk dalam kategori Sehat, 4 perusahaan berkategori Rawan dan 13 perusahaan berkategori Potensi Bangkrut. Prediksi keberlangsungan usaha dilakukan agar perusahaan dapat mengetahui sedini mungkin adanya potensi-potensi kebangkrutan dan meminimalisir potensi tersebut di masa mendatang. Prediksi ini juga membantu manajer dalam menilai performa dan operasional perusahaan, dan menentukan apakah perusahaan telah memiliki performa yang baik atau belum. Penelitian selanjutnya dapat menguji model yang sama pada sektor lain di BEI, dan juga pada hotel dan yang belum terdaftar di BEI.
\end{abstract}

Kata Kunci: Keberlangsungan Usaha; COVID-19; Z-Score; Hotel, Restoran dan Pariwisata.

\section{PREDICTION OF THE BUSINESS CONTINUITY OF THE HOTEL, RESTAURANT AND TOURISM SUB SECTOR COMPANIES IN THE ERA OF THE COVID-19 PANDEMIC}

\begin{abstract}
Predicting business continuity is very important because it will describe the financial condition of the hotel, restaurant and tourism sub-sector companies affected by the COVID-19 pandemic. A total of twenty-nine (29) hotel, restaurant and tourism sub-sector companies listed on the Indonesia Stock Exchange in 2020 became the object of research. In assessing the sustainability of the company, this study uses a modified Altman Z-Score model, which consists of four (4) ratios. These ratios include: working capital divided by total assets, retained earnings divided by total assets, EBIT divided by total assets, and book value of equity divided by book value of liability. From this model, the Z-Score value of each company will be obtained, which is then categorized into Healthy, Vulnerable, and Bankrupt Potential categories. This research shows that, of the 29 companies tested, 12 of them are in the Healthy category, 4 companies are in the Vulnerable category and 13 companies are in the Bankrupt Potential category. Prediction of business continuity is carried out so that the company can find out as early as possible the potential for bankruptcy and minimize this potential in the future. This prediction also helps managers in assessing the company's performance and operations, and determining whether the company has performed well or not. Future research can test the same model in other sectors on the IDX, and also on hotels, restaurants and tourism sub-sector companies in companies that have not been listed on the IDX.
\end{abstract}

Keywords : Business Continuity, COVID-19, Hotel, Restaurant, and Tourism

Copyright (C2021. UHN IGB Sugriwa Denpasar. All Right Reserved 


\section{PENDAHULUAN}

Fenomena pandemi akibat virus COVID-19 memberikan dampak perubahan signifikan, terutama pada sektor perekonomian World Health Organization pada tahun 2020 mencatatkan jumlah kasus sebanak 385.890 kasus di Indonesia. Perekonomian Indonesia sesuai data BPS terkontraksi menjadi $-5,32 \%$, akibat daya beli mesyarakat yang menurun serta kekhawatiran akan aturan pemerintah terkait Pembatasan Sosial Berskala Besar (PSBB) yang berdampak pada banyaknya perusahan yang gulung tikar.

Pandemi COVID-19 berimplikasi pada keberlangsungan usaha, di mana banyak perusahaan mengalami kesulitan keuangan (Wang et al., 2020). Ketika perusahaan mengalami penjualan yang anjlok, maka ini akan berimplikasi pada arus kas perusahaan. Arus kas negatif terus menerus, inefisiensi perusahaan dapat memicu kebangkrutan pada perusahaan (Altig et al., 2020; Didier et al., 2021; Hunter \& Shannon, 2020; Iverson et al., 2011; Usheva \& Vagner, 2021)

Survey yang dilakukan oleh dari BPS pada tanggal 10-17 Juli 2020 menemukan menyatakan bahwa dari setiap 100 usaha hotel dan restoran, 92 di antaranya mengalami penyusutan pendapatan. Begitu pula dengan data BPS, di bulan Januari hingga April 2020, yang menunjukkan bahwa wisatawan mancanegara yang datang ke Indonesia turun $45,01 \%$ dibandingkan periode yang sama di tahun sebelumnya.

Laporan keuangan memiliki informasi yang komprehensif yakni mengenai operasional, pencapaian, dan posisi keuangan. Laporan keuangan yang diaudit menjadi salah satu dasar dalam pengambilan keputusan yang diandalkan tidak hanya oleh para investor, namun juga stakeholder lainnya (Amedu, 2012; Blessing \& Onoja, 2015; Duréndez Gómez-Guillamón, 2003; Hodge \& Pronk, 2006; Nguyen et al., 2016). Situasi saat ini di mana banyaknya aturan mengenai pembatasan-pembatasan ekonomi yang terjadi, pertanyaan yang juga muncul adalah terkait kemampuan laporan keuangan untuk menangkap fenomena ini dan angka yang disajikan pada laporan keuangan dapat digunakan untuk membuat forcasting, prediksi, dan yang terpenting terkait keberlangsungan perusahaan itu sendiri. (Wulandari \& Maslichah, 2021).

Analisis keberlangsungan usaha ini sangat penting dilakukan karena akan menggambarkan kondisi keuangan perusahaan yang terdampak pandemi, mampu memitigasi dan memprediksi going concern perusahaan kedepannya yang berguna sebagai pertimbangan dalam mengambil kebijakan perusahaan. Inilah yang melatarbelakangi penulis untuk melakukan penelitian terkait prediksi keberlangsungan perusahaan, terutama pada sub sektor hotel, restoran dan pariwisata di era pandemi COVID-19.

\section{LITERATUR REVIEW}

\section{Keberlangsungan Usaha}

Keberlangsungan perusahaan menjadi takaran dari keamanan keuangan yang dimiliki perusahaan yang terkait dengan kemampuan pengelolaan dari manajemen sehingga perusahaan dapat terus berjalan. Ini juga yang menjadikan keberlangsungan perusahaan menjadi hal yang penting bagi investor dan stakeholder perusahaan.

Ada beberapa hal yang dapat mengganggu keberlangsungan perusahaan, antara lain (McKeown et al., 1991):

a. Perusahaan mengalami tren negatif, misalnya kerugian operasional yang berulang-ulang, modal kerja yang kurang, perusahaan memiliki arus kas negative, dan buruknya rasio-rasio keuangan yang signifikan.

b. Petunjuk lainnya terkait adanya kemungkinan kesulitan finansial, misalnya kegagalan dalam pemenuhan perjanjian/kewajiban utang, deviden yang tertunggak, pemasok yang menolak pembelian secara kredit biasa, restrukturisasi utang, perlunya metode pembiayaan/pendanaan alternatif, atau aktiva yang sebagian besar dijual. 
c. Masalah di internal, misalnya karyawan yang melakukan mogok kerja atau hubungan ketenagakerjaan yang buruk, perusahaan tergantung pada kesuksesan proyek, adanya komitmen jangka Panjang yang tidak memberikan nilai tambah ekonomis, dan adanya kebutuhan yang signifikan terkait perbaikan operasional.

d. Masalah luar yang sedang dihadapi perusahaan, misalnya adanya gugatan pengadilan kepada perusahaan, peraturan atau perundang-undangan yang menyulitkan, kehilangan paten, lisensi atau franchise, pelanggan dan pemasok utama yang hilang, dan adanya bencana besar yang mengakibatkan kerugian.

Kebangkrutan perusahaan dapat dikaji baik dari faktor internal maupun faktor eksternal. Faktor internal tersebut antara lain:

1. Ketidakefisienan manajemen, yang berimplikasi pada kerugian yang berulang-ulang hingga perusahaan kesulitan dalam melunasi kewajibannya (Fauzia, 2017; Putri et al., 2018) Penyebabnya adalah adanya pemborosan biaya dan manajemen yang kurang terampil dan ahli.

2. Modal yang tidak seimbang dengan jumlah utang-piutang. Apabila jumlah utang tinggi, maka ini akan diikuti dengan tingginya jumlah beban bunga yang harus dibayar perusahaan, sehingga mengakibatkan terkikisnya laba perusahaan, bahkan bisa mengalami kerugian. Apabila piutang terlalu besar, maka itu juga tidak baik karena terlalu banyak aset yang menganggur dan tidak ter-generate menjadi kas.

3. Moral hazard yang dilakukan oleh manajemen, dimana ini termasuk ke dalam bentuk kecurangan. Kecurangan yang dimaksud bisa dalam hal korupsi, misinformasi yang menyesatkan para pengguna laporan keuangan.

Dari sisi faktor eksternal antara lain:

a) Pelanggan mengalami perubahan kebutuhan atau keinginan yang belum diprediksi sebelumnya oleh perusahaan, sehingga pembeli mencari perusahaan lain yang mampu mampu memenuhi keinginannya, dan berdampak pada penurunan pendapatan.

b) Pemasok tidak dapat menyediakan bahan baku yang diperlukan perusahan untuk kegiatan produksi.

c) Kegagalan Debitur dalam melakukan pembayaran, atau terlalu lama dalam melakukan pengembalian sehingga banyak aset menganggur terlalu lama dan perusahaan tidak mendapat aliran kas.

d) Tidak memiliki hubungan yang harmonis kepada kreditur.

e) Ketatnya persaingan bisnis dengan perusahaan lainnya.

f) Kondisi perekonomian global, misalnya adanya pandemi COVID-19 menjadi kondisi yang mempengaruhi perekonomian secara global.

Dalam mendeteksi keberlangsungan perusahaan, model prediksi yang digunakan dapat mengadopsi Altman Z-Score. Terdapat 4 rasio Altman untuk menghitung Z-Score, khususnya perusahaan non manufaktur (Altman, 2000), yang dengan kata lain sangat sesuai untuk memprediksi perusahaan sektor hotel, restoran dan pariwisata, antara lain:

a) Modal kerja dibagi total aset, merupakan besaran aset likuid bersih perusahaan relatif terhadap total kapitalisasi. Working Capital atau modal kerja sendiri selisih antara aset lancar dan hutang lancar. Perusanaan yang mengalami rugi operasi terus menerus akan memiliki aset lancar yang terus menurun, jika kita kaitkan dengan total aset.

b) Laba ditahan dibagi total aset, di mana rasio ini digunakan untuk mengetahui performa perusahaan dalam mencetak laba dari total aset yang dimiliki. Akun laba ditahan mencerminkan laba/kerugian yang diinvestasikan kembali selama perusahaan berjalan.

c) EBIT dibagi total aset, untuk mengukur besarnya keuntungan sebelum bunga dan pajak yang mampu dicetak perusahaan dari total aset yang dimiliki. Ini merupakan ukuran produktivitas perusahaan yang sebenarnya, karena mereduksi faktor pajak dan hutang.

d) Book Value Equity dibagi Book Value of 
Liability, mengukur besarnya dampak liabilitas/hutang terhadap turunnya nilai aset perusahaan.

\section{METODE}

\section{Objek Penelitian}

Penelitian ini menjadikan perusahaan sub sektor hotel, restoran dan pariwisata yang terdaftar di Bursa Efek Indonesia pada tahun 2020 sebagai objek penelian karena berdasarkan survey yang dilakukan oleh dari BPS pada tanggal 10-17 Juli 2020 menemukan menyatakan bahwa dari setiap 100 usaha hotel dan restoran, 92 di antaranya mengalami penyusutan pendapatan. Begitu pula dengan data BPS, di bulan Januari hingga April 2020, yang menunjukkan bahwa wisatawan mancanegara yang datang ke Indonesia turun $45,01 \%$ dibandingkan periode yang sama di tahun sebelumnya.

\section{Pengumpulan Data}

Penelitian ini menggunakan data sekunder yakni data laporan keuangan tahun 2020 yang telah diaudit milik perusahaan yang terdaftar di Bursa Efek Indonesia, laporan tahunan (annual report) dan data harga saham perusahaan. Penulis juga melakukan studi Pustaka pada penelitianpenelitian yang sudah lebih dulu dilakukan, artikel serta literatur terkait.

\section{Alat Analisis Data}

Adapun alat analisis data dalam penelitian ini adalah model Z'-score modifikasi yang diciptakan oleh Edward Altman. Model Z-score modifikasi ini menilai tingkat kesehatan perusahaan nonmanufaktur, yang berarti ini tepat untuk menilai keberlangsungan usaha perusahaan sub sektor hotel, restoran dan pariwisata, dengan rumus sebagai berikut.

\section{$Z=6,56 X 1+3,26 X 2+6,72 X 3+1,05 X 4$}

Keterangan:

$\mathrm{Z}=$ Skor/indeks keseluruhan

$\mathrm{X} 1=$ Modal kerja/total aset

$\mathrm{X} 2=$ Laba Ditahan/Total aset

$\mathrm{X} 3=$ Laba sebelum bunga dan pajak/total aset
$\mathrm{X} 4=$ book value of equity / book value of liability

Dari Analisa model Z Score modifikasi di atas akan diperoleh nilai $Z$ yang diklasifikasikan ke dalam tiga (3) a kategori berikut.

1. Z' > 2,9, dikategorikan sebagai perusahaan yang sehat

2. Z'-score dari nilai 1,23 hingga 2,90, dikategorikan sebagai perusahaan di daerah abu-abu (grey area)

3. Z-score di bawah 1.21 dikategorikan sebagai perusahaan yang berpotensi bangkrut.

\section{HASIL DAN PEMBAHASAN}

29 perusahaan sub sektor hotel, restoran dan pariwisata yang terdaftar di BEI dianalisa laporan keuangannya untuk mendapatkan nilai Z-Score. 29 perusahaan tersebut antara lain: BAYU, CLAY, DFAM, EAST, FAST, FITT, HOTL, HRME, ICON, INPP, JGLE, JHID, JSPT, KPIG, MAPB, MINA, NASA, NATO, PANR, PDES, PGJO, PGLI, PJAA, PNSE, PSKT, PTSP, PZZA, SHID, dan SOTS. Berdasarkan perhitungan Z'score dan membandingkannya dengan kriteria yang ditentukan maka didapatkan hasil nilai Z'score sebagai berikut.

Tabel 1. Nilai Z-Score Perusahaan Sub Sektor Hotel, Restoran dan Pariwisata Tahun 2020

\begin{tabular}{cccc}
\hline No & Kode & Z-Score & Kategori \\
\hline 1 & BAYU & 5,16 & Sehat \\
2 & CLAY & $(0,89)$ & Potensi Bangkrut \\
3 & DFAM & 0,70 & Potensi Bangkrut \\
4 & EAST & 14,50 & Sehat \\
5 & FAST & 0,76 & Potensi Bangkrut \\
6 & FITT & $(0,61)$ & Potensi Bangkrut \\
7 & HOTL & $(0,46)$ & Potensi Bangkrut \\
8 & HRME & 1,96 & Rawan \\
9 & ICON & 4,76 & Sehat \\
10 & INPP & 4,16 & Sehat \\
\hline
\end{tabular}




\begin{tabular}{cccc}
\hline \hline No & Kode & Z-Score & Kategori \\
\hline 11 & JGLE & 2,97 & Sehat \\
12 & JIHD & 3,07 & Sehat \\
13 & JSPT & 2,30 & Rawan \\
14 & KPIG & 5,07 & Sehat \\
15 & MAPB & $(0,72)$ & Potensi Bangkrut \\
16 & MINA & 24,00 & Sehat \\
17 & NASA & 19,28 & Sehat \\
18 & NATO & 722,83 & Sehat \\
19 & PANR & $(0,34)$ & Potensi Bangkrut \\
20 & PDES & $(2,96)$ & Potensi Bangkrut \\
21 & PGJO & 24,47 & Sehat \\
22 & PGLI & 2,30 & Rawan \\
23 & PJAA & $(0,56)$ & Potensi Bangkrut \\
24 & PNSE & 0,55 & Potensi Bangkrut \\
25 & PSKT & 2,96 & Sehat \\
26 & PTSP & $(0,98)$ & Potensi Bangkrut \\
27 & PZZA & 1,01 & Potensi Bangkrut \\
28 & SHID & 2,05 & Rawan \\
29 & SOTS & 0,91 & Potensi Bangkrut \\
\hline & Sumber: Data Sekunder Diolah (2021) \\
& D &
\end{tabular}

Pada tahun 2020, dari 29 perusahaan sub sektor hotel, restoran dan pariwisata yang terdaftar di BEI, 12 perusahaan kategori Sehat (40\%), 4 perusahaan kategori Rawan (14\%) dan 13 perusahaan kategori Bangkrut (45\%). Adapun rinciannya adalah sebagai berikut.

\section{Kategori Sehat}

Sebanyak 12 perusahaan yang termasuk kategori perusahaan sehat, antara lain BAYU, EAST, ICON, INPP, JGLE, JIHD, KPIG, MINA, NASA, NATO, PGJO dan PSKT.

\section{Kategori Rawan}

Sebanyak 4 perusahaan yang termasuk kategori perusahaan Rawan, antara lain HRME, JSPT, PGLI, dan SHID.

3. Kategori Bangkrut

Sebanyak 13 perusahaan yang termasuk kategori perusahaan Bangkrut, antara lain CLAY, DFAM, FAST, FITT, HOTL, MAPB, PANR, PDES, PJAA, PNSE, PTSP, PZZA, dan SOTS.

Analisa terhadap Catatan atas Laporan Keuangan serta Laporan Auditor Independen pada perusahaan yang masuk dalam kategori Bangkrut menunjukkan kondisi yang dihadapi semasa pandemi sebagai berikut.

1. CLAY mengalami penurunan penjualan pada tahun 2020, laba ditahan defisit yang dikarenakan adanya persaingan bisnis hotel yang ketat untuk mendapatkan pangsa pasar, sehingga laba operasional belum maksimal, ditambah adanya pandemi Covid-19 selama tahun 2020, sehingga meningkatkan saldo defisit yang signifikan.

2. FAST tidak mampu memenuhi salah satu perjanjian pinjaman antara perusahaan dengan bank yakni rasio kecukupan EBITDA terhadap beban bunga dan rasio cakupan utang. FAST mengalami penurunan penjualan untuk tahun yang berakhir pada 31 Desember 2020 dan berimplikasi pada pada laporan laba rugi menunjukkan kerugian bersih.

3. FITT terdampak pada kegiatan operasional sejak awal 2020. FITT juga melakukan restrukturisasi fasilitas kredit/ pinjaman bank.

4. HOTL mengalami dampak kerena operasi bisnis yang dibatasi selama tahun pelaporan dan diperkirakan dampak tersebut masih akan dirasakan hingga periode ke depan yang belum bisa ditentukan.

5. PANR dan PDES merupakan satu grup perusahaan yang bergerak di bidang inbound dan outbound. Grup ini terkena dampak pandemi Covid-19 pada bulan Maret 2020, dan mengalami pendapatan yang sangat signifikan di tahun 2020 .

6. PJAA mengalami penurunan pendapatan tiket yang signifikan, karena jumlah pengunjung menurun akibat adanya aturan pembatasan kuota kunjungan per hari.

7. PNSE mengalami dampak pandemi COVID-19 pada Grup yaitu mengalami penurunan pendapatan, kerugian komprehensif berulang, hutang lancar yang melebihi aset lancarnya, serta kekurangan arus kas yang signifikan. 
8. Perusahaan PTSP mengalami dampak signifikan yang mencakup: terdapat karantina di beberapa wilayah; Berkurangnya aktivitas operasi transportasi umum; Pembatasan jam buka operasional mall; Menghindari perjalanan yang tidak mendesak.

9. Perusahaan SOTS mengalami kerugian, hutang lancar lebih tinggi dari aset lancar, dan mengalami defisit keuangan.

Kondisi keuangan yang dialami perusahaan-perusahaan dengan kategori Potensi Bangkrut ini memberikan dampak buruk bagi perusahaan, khususnya perusahaan go public yang akan berpengaruh pada turunnya kepercayaan investor, maupun stakeholder lainnya. Karenanya, manajemen harus mengambil sikap agar mencegah terjadinya kebangkrutan, khususnya bagi perusahaan yang berada di risiko tinggi kebangkrutan atau zona merah.

2 solusi yang bisa dilakukan apabila perusahaan menghadapi arus kas negating yang mengakibatkan perusahaan kesulitan memenuhi kewajiban pelunasan hutangnya yaitu (Pustylnick, 2012):

a) Melakukan Restrukturisasi utang, yakni bernegosiasi terkait perpanjangan waktu pelunasa utang sehingga kas perusahaan dalam kondisi yang aman.

b) Melakukan perubahan pada manajemen, apabila dipandang perlu. Perusahaan dapat melakukan perombakan pada manajemen lama yang dianggap kurang kompeten, sehingga bisa mengembalikan performa perusahaan menjadi lebih baik, sehingga stakeholder kembali bisa menaruh kepercayaan kepada perusahaan, dan menghindari larinya investor akibat kondisi perusahaan yang berpotensi bangkrut.

\section{SIMPULAN}

Simpulan yang dapat ditarik dari pembahasan di atas sebagai berikut.

1. Pada masa pandemi COVID tahun 2020, dari 29 perusahaan sub sektor hotel, restoran dan pariwisata yang terdaftar di BEI, 12 perusahaan termasuk dalam kategori Sehat (40\%), 4 perusahaan berkategori Rawan
(14\%) dan 13 perusahaan berkategori Bangkrut (45\%).

2. Kelangsungan usaha perusahaan tergantung pada kemampuan perusahaan untuk membiayai operasional di masa mendatang seta pencapaian rencana manajemen dan dukungan pemegang saham perusahaan secara terus menerus.

Prediksi keberlangsungan usaha dilakukan agar perusahaan dapat mengetahui sedini mungkin adanya potensi-potensi kebangkrutan dan meminimalisir potensi tersebut di masa mendatang. Prediksi ini juga membantu manajer dalam menilai performa dan operasional perusahaan, dan menentukan apakah perusahaan telah memiliki performa yang baik atau belum.

Penelitian selanjutnya dapat menguji model yang sama pada sektor lain di BEI guna memprediksi keberlanjutan perusahaan di sektor lain di masa pandemi COVID-19. Penelitian selanjutnya juga dapat menguji model ini pada hotel, restoran dan pariwisata non-publik atau yang belum terdaftar di BEI.

\section{REFERENSI}

Altig, D., Baker, S., Barrero, J. M., Bloom, N., Bunn, P., Davis, S. J., Meyer, B., Mihaylov, E., Mizen, P., Parker, N., Renault, T., Smietanka, P., \& Thwaites, G. (2020). Economic Uncertainty Before and During the COVID-19 Pandemic.

Altman, E. I. (2000). Predicting Financial Distress of Companies: Revisiting the Z-Score and Zeta ${ }^{\circledR}$ Models. In Angewandte Chemie International Edition, 6(11), 951-952.

Amedu, M. A. (2012). Role of Financial Statement in Investment Decision Making (A Case Study of First Bank of Nigeria PLC. עלון הנוטע, 66(December), 37-39.

Blessing, A., \& Onoja, E. E. (2015). The role of financial statements on investment decision making: a case of united bank for africa plc (2004-2013). European Journal of Business, Economics and Accountancy, 3(2), 12-37.

Didier, T., Huneeus, F., Larrain, M., \& 
Schmukler, S. L. (2021). Financing firms in hibernation during the COVID19 pandemic. Journal of Financial Stability, 53. https://doi.org/10.1016/j.jfs.2020.10083 7

Duréndez Gómez-Guillamón, A. (2003). The Usefulness of the Audit Report in Investment and Financing Decisions. Managerial Auditing Journal, 18(February), 549-559. https://doi.org/10.1108/0268690031048 2687

Fauzia, I. Y. (2017). Mendeteksi Kebangkrutan Secara Dini Perspektif Ekonomi Islam. EKUITAS (Jurnal Ekonomi Dan Keuangan), 19(1), 90. https://doi.org/10.24034/j25485024.y20 15.v19.i1.1758

Hodge, F., \& Pronk, M. (2006). The impact of expertise and investment familiarity on investors' use of online financial report information. Journal of Accounting, Auditing and Finance, 21(3), 267-292. https://doi.org/10.1177/0148558X06021 00304

Hunter, R. J., \& Shannon, J. H. (2020). Managing Financial Stress for Debtors and Creditors in the Midst of a Pandemic Part I: Security Interests under Article 9 of the UCC. International Journal of Business Management and Commerce, 5(3), 1120.

Iverson, B., Ellias, J. A., \& Roe, M. (2011). Estimating the Need For Additional Bankruptcy Judges in Light of tha COVID-19 Pandemic. 28(6), 4-6.

McKeown, J. C., Mutchler, J. F., \& Hopwood, W. (1991). Toward An Explanation of Auditor Failure to Modify The Audit Reports of Bankrupt Companies. Auditing : A Journal of Practice \& Theory, Supplement, 1-13.

Nguyen, L. T. M., Gallery, G., \& Newton, C. (2016). The Influence of Financial Risk Tolerance on Investment Decisionmaking in A Financial Advice Context. Australasian Accounting, Business and
Finance Journal, 10(3), 3-22. https://doi.org/10.14453/aabfj.v10i3.2

Pustylnick, I. (2012). Restructuring the financial characteristics of projects in financial distress. Global Journal of Business Research, 6(2), 125-135.

Putri, E. L., Haryanto, S., \& Firdaus, R. M. (2018). Mampukah Good Corporate Governance dan Risiko Kredit Sebagai Prediktor Financial Distress? AFRE (Accounting and Financial Review), l(1), 26-35. https://doi.org/10.26905/afr.v1i1.2291

Usheva, M., \& Vagner, L. (2021). Earnings Management as a Tool of Bankruptcy Prevention during Global Pandemic of COVID-19. SHS Web of Conferences, 92, 02063. https://doi.org/10.1051/shsconf/2021920 2063

Wang, J., Yang, J., Iverson, B. C., \& Kluender, R. (2020). Bankruptcy and the COVID-19 Crisis. SSRN Electronic Journal. https://doi.org/10.2139/ssrn.3690398

Wulandari, E. Y., \& Maslichah. (2021). Penggunaan Model Springate, Ohlson, Altman Z-Score, dan Grover Score Untuk Memprediksi Financial Distress pada Masa Pandemi COVID-19 (Studi pada Perusahaan Manufaktur yang Terdaftar di Bursa Efek Indonesia). EJra, 10(05), 90-103. http://riset.unisma.ac.id/index.php/jra/ar ticle/view/10620 